\title{
Ideologically-based Polarisation and Racism in Discourse
}

Dalia M. Hamed

Department of Foreign Languages (English), Faculty of Education - Tanta University, Egypt.

E-mail: daliahamed53@yahoo.com

\begin{abstract}
"The privileged" against "the others", "Us" against "Them", "the Top" against "the Bottom" and "the Citizen" against "the Refugee/Immigrant"- are all ideologically-based discourses that classify human beings. The present study, being discourse analytical, aims to shed light on some discourses of polarization that are ideologically based and detect examples of such discourses in various fields as politics, science, sport and education. Methodological framework is based on Van Dijk's models of ideological discourse analysis (2006a, 2006b \&2007). Accordingly, a critical analysis of these discourses is applied in order to decode the meaning that lies deep within them, a meaning that reveals the deeply-rooted ideology that makes some believe that they deserve to be "the privileged" while other people are "the others" that are not privileged. Van Dijk's model of ingroup-outgroup polarization (Emphasizing Our good things and Their bad things; Mitigating Our bad things and their good things) stands as a comprehensivelabstract standard that is to be detected in the data of this study. The paper concludes that the critical analysis of discourse has shown polarization/racism to be widespread in different fields of life. It calls for making changes in the way people think and conceive of "the others"- a first step towards a better socio-political atmosphere.
\end{abstract}

Keywords: Ideology; Racism; Polarization; Critical Discourse Analysis

\section{Introduction}

Actions and reactions, whether verbal or physical, are far from being innocent reflections of spontaneous sensations. Any verbal or physical behaviour is motivated by a deeply-rooted idea. This idea is formed across different stages of life so that it may build an attitude: a stance. The long-established idea and its consequent position(s) are responsible for every word uttered, every stand adopted and every action taken. On having an almost comprehensive look at the world with its differing countries and diverse regions; it becomes obvious that polarisation is as wide-spread as it has never been. As an ideology, polarisation means that persons who adopt a polarised ideology never tolerate "the others". "The others", in this sense are any persons belonging to a different group. "The others" are considered, by ideologically-polarised adopters, to be belonging to a remote sector or a distant category which is less privileged.

Consequently, ideologically-polarised adopters, or the privileged, neither accept "the others" nor feel content with their very existence. "The others" are always the target of attack by the privileged who always strive to show their superiority in comparison with the inferiority of "the others". Discourse is a major outlet for the privileged to express their ideologically-based preponderance over "the others". As a result, we are surrounded with polarised discourses that divide people into layers, split them into sections and categorise them according to nationality, religion, birth or education. These discourses of antipathy give rise to the present study. Van Dijk (2006a) discusses the point that politics is a fertile soil for ideologically-based discourse. This is true, indeed, as political discourse is about a struggle between differing ideologies manifest through politicians' words. This paper proves that polarised discourse is everywhere in science, education, politics and sports.

\section{Problem Statement}

"The privileged" against "the others", "Us" against "Them", "the Top" against "the Bottom" and "the Citizen" against "the Refugee/Immigrant"- all are ideologically-based discourses that classify human beings. These polarised-style texts are of importance; this is because, according to Fairclough (2003), texts are considered in Critical Discourse Analysis because of their effect on maintaining/changing ideologies. Moreover, discourse is a form of social practices (Fairclough 1992). A social practice, Fairclough adds, 
is any form of activity including, in addition to discourse, the spatial conditions of the utterance, its temporal setting, the participants, their status and their beliefs/ideologies. Accordingly, people's words are not just uttered linguistic elements, they are social actions. By these actions, relations and ideological systems in the status quo may be affected.

Discourses of hatred result in negative effects among social actors. Consequently, conflicts are expected to dominate. Any change in actions must be preceded by a modification of the related discourses, a thing which needs an accurate detection and identification of these discourses of polarisation. In this study, these discourses of hatred are traced in the fields of politics, science, education and sport. They are analysed according to Van Dijk models of critical discourse analysis (2006a, 2006b \&2007), that will be explained in the review section.

\section{Aim and Significance of the Research}

The present study, being discourse analytical, aims to shed light on some discourses of polarisation that are ideologically based and to detect examples of such discourses in differing fields and diverge parts of the world. Critical analysis of these discourses is applied in order to decode meaning that lies deep within these discourses, a meaning that reveals the deeply-rooted ideology that makes some believe that they deserve to be "the privileged" while other people are" the others" that are not privileged. This study is significant in the sense that it draws attentions to struggling ideologies and their representation in discourse(s). It calls for making changes in the way people think and conceive of "the others"- a first step towards a better socio-political atmosphere.

\section{Research Questions}

i. What is meant by "ideology"?

ii. What is "ideologically-polarised discourse"?

iii. What are examples detected to prove ideologically-polarised discourse?

iv. What are the consequences of polarisation, as an ideology manifest in discourse, on the worldpeace?

\section{Literature Review}

\section{Related Literature}

\section{Discourse}

Following Chilton's distinction between language, the universally-human ability to learn and practice any language, and a language that refers to a specific tongue as English (Chilton 2004), a discourse can be differentiated from discourse. A discourse is used to denote a certain type of language used within a particular field such as a political discourse and a scientific discourse used within the domains of politics and science respectively. Discourse, on the contrary, is the unique feature of human interaction, an interaction that may take verbal, written or semiotic forms at any linguistic level. Discourse is any form of social interaction/communication. This means that a sound as "ah" or a glimpse of an eye are considered to be forms of discourse as long as some sort of communication is established. This orientation may be contrastive to that of Schiffrin et al. (2001) as they state that many linguists define discourse as being whatever beyond the sentence.

Gee $(1990,1996)$ defines discourse in terms of a distinction between 'discourse' with a lower case ' $d$ ' and 'Discourses' with an upper case ' $D$ '. He defines the former as being language components that together make a sense to a certain community. The latter is defined as being an accepted method that relates a citizen to a social group.

\section{Discourse Analysis}

If discourse is used to refer generally to different language patterns in different situations such as medical discourse and political discourse, discourse analysis is the analysis of these patterns (Jorgensen \& Phillips 
2002). The analysis of discourse is to examine the relation between that discourse and its context of utterance (McCarthy 1991).

\section{Critical Discourse Analysis}

According to the nature of their socio-political orientation towards the analysis of discourse, different approaches to discourse analysis can either be critical or non-critical (Fairclough, 1992, 1995). Noncritical studies describe the linguistic phenomenon without delving into its implications and effects on social relations. Critical studies, on the contrary, are concerned with an analytical level beyond mere description. Fowler et al. (1979) and Fowler (1991) are the proponents of the critical trend in linguistic studies which is defined as being an investigation of the relations between language and its socio-historical context (Fowler 1991). Critical Discourse Analysis (CDA), a division in discourse studies, is interested in questions of power relations and "cultural and ideological meaning" in texts (O'Halloran 2005, P. 1946). It also considers language to be a form of social practice (Fairclough 1989). The word "practice" implies the dynamic nature of discourse and denotes that discourse involves many elements that contribute to its constitution. These elements include discourse setting, timing, participants and, mostly important and relevant to the present research, their ideologies.

Critical Discourse Analysis is an approach to language focusing on the manner power abuse; ideology and inequality are activated by people's interaction. Critical Discourse Analysis has to show the relation between the micro level of analysis, at the linguistic level, and the macro level of analysis, that of the way ideology and power are enacted in discourse. (Van Dijk 2001a \&b).Wodak (2001) affirms the previous point that Critical Discourse Analysis reveals the relation between power/control and language. Racism, a form of power abuse, is an ideological tool employed to unjustly treat certain social groups and prevent them from obtaining their due fair rights (Wodak \& Reisigel 2001).

Any form of inequality or power abuse has to be justified. The justification of inequality involves the positive representation of the elite and the negative representation of the Others (Van Dijk 1993). Van Dijk (2007) focuses on the relation between discourse and the systems of ideas/beliefs-ideologies. He considers ideologies to have control on whatever is said and done.

\section{Ideology}

When Herman (1995) discusses the notion of context of an utterance, she mentions that the cognitive context must be focused on so that a thorough understanding of that utterance may be attained. She defines the cognitive context as being is the set of beliefs and assumptions activated by individuals, or rather the ideological system.

Ideologies are defined as the being the fundamental beliefs shared by the social cognitions of groups. These ideologies control group attitudes towards issues as migration and enhance polarisation in society (Van Dijk 2013). Hamilton (1987) reviews 27 elements of ideology. He concludes his article with the definition that an ideology is a system of ideas, beliefs and attitudes in favor of certain patterns of social relations and conducts. Ideologies are defined by Jost (2007) as being the system of belief shared by individuals or groups.

An idea is the minimal unit which gathers with other units of ideas to build an ideology. An influential definition of ideology is that of its being the science and the art of "the spatial expression of ideas" (Nemeth 2006, 243). Ideologies are of a major concern in language research because, according to Inkeles (1958 as cited in Szalay et al. 1972), to understand a person's ideology is a condition to understand his action. This article reverses the direction suggested by Inkeles (1958) as it starts from action, that of language, to understand its underlying ideology. The present article is supported by Van Dijk's beliefs that ideologies control discourse (2002) and that ideologies are articulated, explained and justified through discourse (2011). Ideologies are established as an operation directed against ideological enemies (Van Dijk 1998). 


\section{Related Studies}

Many studies have investigated the relation between discourse and ideology. Apart from Van Dijk who is a pioneer in the field, research in ideological discourse has been regarded. Hodge (2012) analyses the terms of ideology, identity and interaction in their relation to Critical Discourse Analysis. Eissa (2014) examines two online news sites, Egyptindependent and Ikhwanweb, in order to polarised discourse structures in the news reports.

Amer (2017) analyses the media discourse of the Gaza war of 2008-2009 as to the representation of political social actors. Findings suggest that media discourse and news stories of the selected papers are influenced by ideological stances. Persson \& Neto (2018) consider the relation between ideology and discourse in the debates of a Brazilian public university. Their aim is to uncover the embedded ideologies. Bhatia, A. \& Jenks, C.G. (2018) examine US media representation of Syrian refugees and the way media is shaped by political ideologies.

The above-references are some examples of research concerning ideology and discourse. It is noticed that previous work on discourses of polarisation focus on political and media discourse analysis. The fields of sports, science and education are not sufficiently addressed in previous literature. This paper tries to have a wider look at the degree of ideology-breakthrough within daily discourses.

\section{Theoretical Framework: Van Dijk's Model of Critical Discourse Analysis}

Van Dijk (2007) focuses on ideologically-based discourse that follows the general instructions of emphasising "positive things about Us" while stating "negative things about Them". This strategy includes de-emphasising the negative things "about Us" and the positive things "about Them" (44).

Table (1) summarises the nature of ideologically-controlled discourse:

\begin{tabular}{|l|l|}
\hline \multicolumn{1}{|c|}{ Us } & \multicolumn{1}{c|}{ Them } \\
\hline $\begin{array}{l}\text { Emphasize Positive/ De-emphasise } \\
\text { negative things }\end{array}$ & $\begin{array}{l}\text { De-emphasise Positive/ } \\
\text { emphasize negative things }\end{array}$ \\
\hline
\end{tabular}

Table 1: Ideologically-controlled discourse

"Us" and "Them" are used to refer to "The privileged" against "the others", "Us" against "Them", "the Top" against "the Bottom" and "the Citizen" against "the Refugee/Immigrant. The previous ideologies can be enacted in discourse via diverse methods:

1. The selection of certain topics (propositions)/themes (of single words) that serve the represented ideology.

2. The degree of generalisation/specification of details.

3. The choice of explicit/implicit language that serve the positive image of "Us" against the negative image of "Them".

4. Showing the contrast between Us and Them, We and They, Our and Their by stressing the good/ oppressed nature of "Ours" versus the evil/oppressing nature of "Theirs". Examples are useful tools that clarify this contrast.

5. Employing disclaimers via introducing an apparent empathy/effort followed by a "but-clause" that serves as tool emphasizing “Their” badness. (Van Dijk 2007).

Van Dijk (2006 a) presents the strategies of what he calls the ideological square: emphasizing Our goodness and Their badness. He illustrates some features of ideological discourse as: actor description, categorisation, irony and hyperbole.

Van Dijk (2006b) discusses the connection between discourse and ideology and explains that ideological discourse is shaped by positive self-presentation (in-group/boasting) versus negative otherpresentation(out-group/derogation). This rule of ideologically-polarised discourse, he adds, is reflected in texts at multiple levels as meaning, form and action. 
This study utilises Van Dijk's models of ideological discourse presented in Van Dijk (2006a 2006b \&2007). The following model selects some relevant linguistic tools from Van Dijk's previous models so that the following framework will be used to detect polarization in the discourse of science, education, politics and sport.

The general rule of ingroup-outgroup polarisation (Emphasising Our good things and Their bad things; Mitigating Our bad things and their good things) stands as a comprehensive/abstract standard that is to be detected via the coming apparatus presented in table (2):

\begin{tabular}{|l|l|}
\hline Discourse apparatus detecting polarization & \multicolumn{1}{|c|}{ Explanation } \\
\hline Categorization/Polarization of groups & $\begin{array}{l}\text { Using discourse units as immigrants, privileged, refugees, etc. This is a } \\
\text { necessary step paving the way for topicalising and describing Us/Them. }\end{array}$ \\
\hline Topicalisation & Topicalising (bringing in the topic position) Our goodness/Their badness \\
\hline Actor description & Our description (positive) against Theirs (negative) \\
\hline Detailing Our goodness/Their badness & Using illustrations to serve that purpose \\
\hline Contrasting/Comparing & Us versus Them, We versus They, Our versus Their \\
\hline Modality degrees & necessity/probability to represent Our world and Their world \\
\hline Evidentiality & Presenting evidences \\
\hline National self-glorification & Praising Our country \\
\hline Generalisations & Generalizing Their negative features/effects \\
\hline Victimisation & $\begin{array}{l}\text { Using this strategy to show Their evil nature versus Our innocent/ } \\
\text { suffering citizens. }\end{array}$ \\
\hline
\end{tabular}

Table 2: Discourse apparatus detecting polarisation

\section{Research Methodology}

This paper is a Critical Discourse Analysis of many texts relevant to four varying fields in life: politics, education, science and sport. These texts are produced in different countries by differing tongues. Each text is downloaded from the Internet and the relevant online site is documented. Van Dijk's models of the critical investigation of ideology in discourse (2006a, 2006b \& 2007) are the basic methodological frame according to which the texts are investigated.

\section{Analysis and Discussion}

Language is ideologically-controlled. This paper is about polarisation as an ideology and its representation in various discourses pertaining to multiple fields. It is assumed that those who consider themselves as being more privileged than the others follow a certain strategy to make such privileges continue and strive to keep the condition as it is: "Since actors... receive material benefits from the racial order, they struggle to maintain their privileges" (Bonilla-Silva, 2009, 9). This study attempts to analyze polarised discourse and prove the penetration of polarised ideologies in many fields, a thing that may direct attention towards the negative atmosphere prevailing and its detestable consequences. This analysis depends on Van Dijk's models of Critical Discourse Analysis as a framework to check the permeation of polarisation in politics, science, education and sport. The following part is undertaken for that purpose.

\section{Polarization in Politics}

\section{Gebran Bassil}

Gebran Bassil- the Minister of Foreign Affairs of Lebanon, a member of the Lebanese Parliament and head of The Free Patriotic Movement- proves to be a devoted tweeter. His social media posts have sparked severe reactions that share the accusation against Bassil's racism. The Coming part is an illustration of Bassil's some tweets that arouse backlashes amongst social media users. 


\title{
Example (1):
}

On 7 June, Bassil tweets:

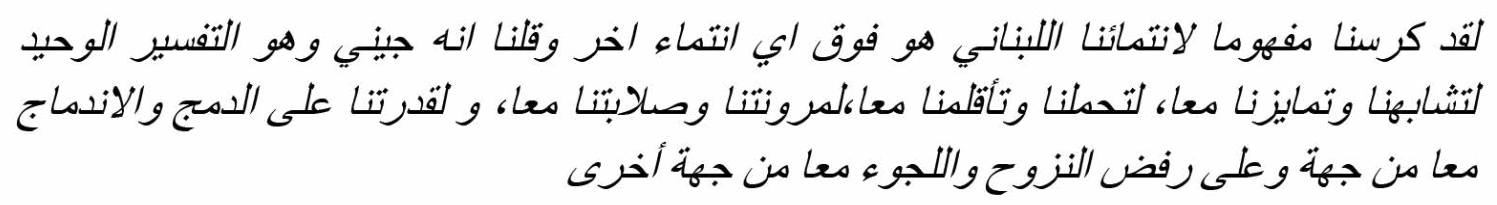

\section{Translation of example (1):}

\begin{abstract}
"We have established the concept for our Lebanese belonging which is above any other belonging. We said that it was genetic and that is the only explanation for our similarity and distinction with each other, for our ability to sustain and accommodate with one another, for our flexibility and strength together, our ability to integrate and be integrated together from one side, and the refusal to be displaced and seeking refuge together from another side."
\end{abstract}

Example (1) is telling a lot about Bassil's ideology. He first divides people according to their genetic structure into two categories: The Lebanese versus The Non-Lebanese, We versus They or Us versus Them. The only criterion considered by him for categorizing people is their genes. Genetically-based categories, in Bassil's own words, are splitting humans into either belonging to Lebanon (The Lebanese/ Us) or to any other country (The Non-Lebanese/Them).

Once genetically-based categories are established, Basil starts to topicalise the goodness of the first category: The Lebanese. He focuses on topics to be remembered about the unique features of The Lebanese. The text is about the uniquely-genetic qualities of The Lebanese.

As soon as the categories and the related topics are set up, Basil starts to describe the main Actor in his words: The Lebanese. The Lebanese are described in length as being a collective in-group "We", which has the same genuine texture, disposition and composition. The description of the Lebanese as a unique in-group is contrasted to that of the Non-Lebanese as being an out-group, those who are referred to as being the refugees.

Giving many details to focus on the positive features of The Lebanese in specific terms is a strategy that helps to make these features implanted in minds. For this reason, Bassil speaks about the similarity, ability, flexibility and the integration of his people. Though the negative features of the non-Lebanese are not stated clearly, their bad traits are inferred when focusing on the valuable merits of the Lebanese as a separate species.

Bassil attempts to implicate that "We" The Lebanese are the privileged class which has to avoid any blend with "Them", the refugees. Bassil's words are stated in a tone carrying high confidence. His confidence stems from his belief that the Lebanese genes are superior to other ones. This is Bassil's evidence that his people are at the top of human race. His glorification of the Lebanese race, his positive remarks about the Lebanese traditions, carries a racist tone because all his words are evidenced by the genetic features of his people.

Bassil uses general language style to refer to the bad effects of the refugees. He refers to the refugees as being an out-group, and a category that is not accepted to be part of the in-group. Bassil's geneticallybased categorisation of human race, The Lebanese in-group (Us/The Good) versus the non-Lebanese outgroup (Them/The Bad), entails that his people would have been victimised had the non-Lebanese been allowed to take refuge in Lebanon.

\section{Example (2):}

Following his ideology of the genetic classification of human race, Bassil posts a purely racist tweet defending the Lebanese workforce. On 8 June, Bassil tweets: 


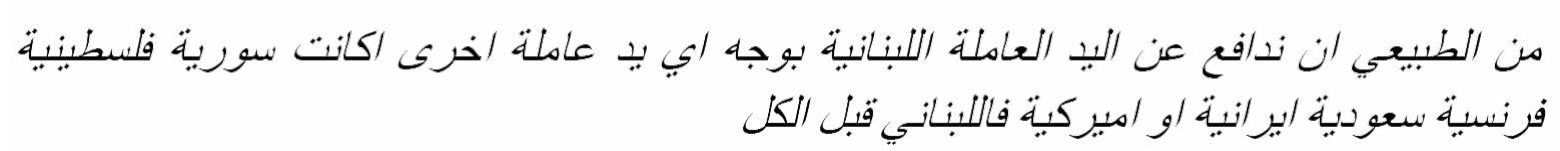

Translation of example (2):

"It is normal to defend the Lebanese labour force against any other foreign labour, whether it be Syrian, Palestinian, French, Saudi, Iranian or American, the Lebanese come first (above all)"(8 June).

Based on example (2), Bassil continues to categorise people genetically: the Lebanese versus the nonLebanese. He topicalises the Lebanese labor force and describes them as being the elite due to their Lebanese genes. He summarises his description of the Lebanese goodness in one clause: "the Lebanese come first (above all)". Bassil declares that he considers the Lebanese, the actor, to be endowed with all advantages which all the other non-Lebanese are lacking. Bassil's deliberate reference to specific nationalities serves two purposes: he succeeds in offending these specific nationalities and in showing a concrete contrast between the Lebanese and the French, the Saudis, the Syrians, the Americans, the Iranians and the Palestinians. Had he mentioned his words in general terms, he would not have underlined the racist idea that the Lebanese are genetically superior to all others.

Bassil's language shows his belief in whatever he states. His self-confidence stems from his lasting proof that the Lebanese genes are a gift that guarantees highness above other genes. His glorification of the Lebanese genes shows his discriminatory attitude. Generalising others' inferiority is a strategy to make his genetic racism an unquestionable cause.

\section{Example (3):}

Bassil also adds:

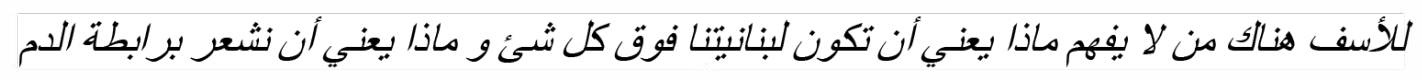

\section{Translation of example (3):}

"Unfortunately, some people do not understand that the Lebanese interests come first, nor do they understand the meaning of the bond of blood" (8 June)

Example (3) seems to be a response directed towards the severe criticism Bassil has been subjected to. Again, Bassil follows the same technique: categorising according to nationality/original blood, topicalizing the Lebanese uniqueness versus others' inferiority, describing the Lebanese preponderance, detailing the Lebanese prevalence through their noble blood bonds, comparing the Lebanese distinction to non-Lebanese lack of understanding, showing complete conviction of words, presenting "the bond of blood" as an evidence justifying the Lebanese excellence over human race, raising Lebanon above all, generalising the bad features of the non-Lebanese by showing their ignorance of the Lebanese invaluable "blood".

The aforementioned examples indicate that Bassil employs a purely racist attitude grading human beings according to their genes: The Lebanese versus the non-Lebanese, We versus They, Us versus Them or the superior in-group versus the inferior out-group. He emphasises the positive representation of his people and the negative representation of others. His image of the Lebanese implies his belief that the Lebanese must not meld with people belonging to differing nationalities for fear that the Lebanese will be victims of others' villainy and unawareness. 


\section{Fraser Anning}

Fraser Anning, an Australian senator and a political figure, shows a purely religion-based racism. Following Christchurch massacre which results in the death of 49 Muslims at two mosques, Anning tweets:

"Does anyone still dispute the link between Muslim immigration and violence?" (https://www.theguardian.com/world/2019/mar/15/australian-senator-fraser-anningcriticised-blaming-new-zealand-attack-on-muslim-immigration ).

Though all victims are Muslims killed while praying, Anning considers Muslim immigrants to be in charge of the terrorist attack on the two mosques. He attacks Islam calling it "the violent ideology of a sixth century despot" and declares: "Just because the followers of this savage belief were not the killers in this instance does not make them blameless" (https://www.newsweek.com/new-zealand-attack-muslimsimmigration-racism-1364132 ).

Anning adopts polarisation according to religion. He splits people into violent Muslims and kind nonMuslims. Anning categorises human beings to be Muslims (extremists and terrorists) or non-Muslims (tolerant and reasonable). He topicalises his ideology that all Muslims adopt radical behaviors. Actor description focuses on presenting the worst and most violent illustration of Islam. Muslims are depicted as being out -group fanatics. Anning's strategy is that of detailing the evils caused by Muslims. Islamic terrorism, in his words, is set against non-Islamic toleration. All these racist ideas are stated in a highlyconfident style representing Islam as the core of all disasters. Anning depends on generalised statements deforming Muslims so that his anti-Islamic ideology may be taken for granted. By equating Islam with violence, Anning presents all non-Muslims to be victims of Islamic extremism.

\section{Donald Trump}

Donald Trump, the American president, is famous for his controversial tweets that carry racist remarks: "Iran leadership doesn't understand the words 'nice' or 'compassion,' they never have. Sadly, the thing they do understand is Strength and Power, and the USA is by far the most powerful Military Force in the world, with 1.5 Trillion Dollars invested over the last two years alone... Iran's very ignorant and insulting statement, put out today, only shows that they do not understand reality..." (25 June)

Trump's polarising ideology classifies persons into Americans (We/Us) versus Iranians (They/Them). Americans, the first category, are topicalised as the powerful in-group, described as being rational and potent and illustrated as being privileged and forceful. Trump's indication of accurate figures is a strategy to prove his statements.

His specification of America's force as a positive exemplification of its distinguished position in the world is contrasted with his illustration of the Iranian image. The Iranians are Trump's second category. They are represented as being topics of derogation. They are further described as being outgroup members who share bad features. Trump explains Iranians' evil points in details showing them to be cruel and stupid. Trump's style of self-trust is shown in his choice of the emphatic structure "do not understand". Glorifying America is Trump's attempt to intensify the ideologically-based polarisation between America as the strongest worldly-power and all other nations, including Iran, that are weaker. It is not surprising that the Iranian president, Hassan Rouhani, replies in a similar offensive tone describing Trump as "suffering from mental disability" (https://edition.cnn.com/2019/06/25/politics/iran-rouhanisays-us-lying-talks-intl/index.html ).

This is not political discourse; it is racist discourse. Politics is the art and technique of getting the best chance out of many possible ones. Political discourse should depend on reason and logic in order to achieve the best performance. Bassil, Anning, Trump and Rouhani share one feature: that of categorising the world into two divisions: the elite/the privileged (in-group members) versus the mob/the unprivileged (out-group members). Genes, religion and nationality are the criteria of dividing human beings in political figures' ideologically-racist discourse. 


\section{Polarisation in Science}

\section{Example (1):}

James Watson, a DNA scientist and an American Nobel Prize winner, has declared some shocking claims over race. Watson repeats his view that the black people are inherently less intelligent than the white. In a TV documentary presented in January 2019, he explains:
"all our social policies are based on the fact that their intelligence is the same as ours - where all the testing says not really" (https://www.iol.co.za/news/world/dna-pioneer-stripped-of- titles-for-claiming-black-people-are-less-intelligent-18805690).

It is apparent that Watson's ideology is based on genetic-racism. Genetics is his criterion of divisions. According to the colour of their skin, Watson splits human beings into two categories: the white people (the more intelligent) versus the black people (the less intelligent). Once such racially-based classification is set, Watson speaks clearly about his intended topic which is the worthiness of the white and worthlessness of the black people. Description of white people as being more intelligent is opposed to that of the black as being less intelligent. In this concern, the white (Us/Ours) are the in-group members granted intelligence due to their genes. On the contrary, the black (Them/Theirs) are the out-group members deprived of intelligence because of their black genes. Being endowed with lack of intelligence is an illustration of the black people's badness. This is because innumerable problems are caused by stupidity.

Comparing the White people's intelligence (Ours) with the black people's lack of intelligence (Theirs) is presented as a scientific reality that is not to be doubted. This effect is the result of using the present simple tense which refers to pure facts and scientific truths. Watson's words are to be evidential themselves, being words uttered by a DNA pioneer. He raises the white above the black and considers the white people to be innocent victims of social policies which equate all people regardless of their colour. Generalising the black's lack in intelligent abilities serves to make the issue an undeniable one.

\section{Example (2):}

Another shocking point is the revival of race science. Some researchers and psychologists claim that some races are inherently more intelligent than others:

The claim that there is a link between race and intelligence is the main tenet of what is known as "race science" or, in many cases, "scientific racism". Race scientists claim there are evolutionary bases for disparities in social outcomes - such as life expectancy, educational attainment, wealth, and incarceration rates - between racial groups. In particular, many of them argue that black people fare worse than white people because they tend to be less naturally intelligent (https://www.theguardian.com/news/2018/mar/02/the-unwelcomerevival-of-race-science).

It is a shock to discuss scientific racism because science has nothing to do with racism. Categorising people according to their race is a repulsive strategy. Yet, some believe in this racial classification between the white versus the black, the in-group intelligent individuals versus the out-group stupid ones, the privileged versus the underprivileged and the superiority of the white coloured-skin versus the inferiority of black-coloured skin.

\section{Polarisation in Sport}

\section{Example (1):}

Being the most popular sport worldwide, football receives obvious attention in the media. Football players, consequently, are also the target of media coverage. In December 2018, Raheem Sterling, Manchester City forward, accuses British media of racism when it comes to its portrayal of black and white athletes (https://theundefeated.com/features/raheem-sterling-manchester-city-chelsea-and-the-racist-mediacoverage-of-black-athletes/ ). 


\title{
Example (2):
}

Mesut Ozil, a German professional footballer of a Turkish descent, was severely criticised after sitting for dinner with Recep Tayyip Erdogan, Turkish president. Ozil declared that he will no longer play international football for Germany and tweeted in July 2018 saying:

\begin{abstract}
In the eyes of Grindel and his supporters, I am German when we win, but I am an immigrant when we lose. I feel unwanted and think that what I have achieved since my international debut 2009 has been forgotten. Despite paying taxes in Germany...I am not still accepted into the German society. I am treated as being 'different' (https://www.thenewsminute.com/article/i-am-german-when-we-winimmigrant-when-we-lose-mesut-ozil-quits-germany-over-racism-85234 ).
\end{abstract}

Ozil represents an ugly image of the German society, an image of genetic discrimination. Ozil is condemned for sitting with Erdogan as both share the same Turkish blood. The German society identifies two genetic categories: the purely-German blood category (having German origins) and the hybrid-German blood one (the immigrants). Ozil topicalises this racial segregation that causes the unjust treatment of immigrants. Ozil is the actor described in words evoking bitterness and reflecting his deepest sense of distress. He illustrates in details all his genuine efforts to be a devoted German citizen. These efforts are met with social ingratitude due to Ozil's Turkish roots.

Ozil draws an image that characterises the German society in racially-distorted manner. He presents the genetic-based discrimination between the pure Germans and the immigrants: the unmixed blood versus the hybrid blood, the elite versus riffraff, the desired citizens versus the undesired immigrants and the similar citizens versus the dissimilar intruders. He uses a confirmed linguistic style to emphasise the social oppression he suffers from. He lists evidences to confirm the fact that though he carries out all his duties as a German citizen, he is offended as an unwanted outsider. Ozil generally expresses his grief at his efforts that have been in vain. He proves himself to be a victim of an ungrateful society by enumerating the various duties and services he undertakes. It is normal that Ozil abstains from praising Germany in this condition.

\section{Example (3):}

Another form of polarisation in sport takes place in Egypt. All Egyptian media, such as Veto, El Watan and El Youm 7, always label AL- Ahly and Al-Zamalek match as The Top/Summit meeting or the Egyptian two-pole match:

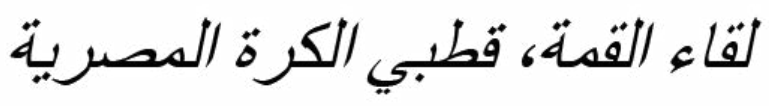

\section{Translation of example (3):}

"The top/summit match, the two poles of the Egyptian football"

The media discrimination exhibited by the Egyptian media divides all teams into two categories: the top teams (Al-Ahly and Al-Zamalek) versus the bottom teams (all other teams). This means that all Egyptian teams and players are damned unless they belong to Al-Ahly or Al-Zamalek. This will never be an atmosphere that motivates success. It is an atmosphere that considers the top restricted to two specific teams. This discrimination is based on the past history of both teams. It means that no matter how any player exerts efforts, he will never be considered to be distinguished as long as he does not belong to either top team in Egypt.

\section{Polarisation in Education}

Polarisation in education is a form educational racism is considered to be a popular attitude among all Egyptians. The Egyptian society with all its sectors classifies science and knowledge and the relative studies. The Faculty of Medicine, Engineering and Pharmacy are called "The Top". As a result, all other faculties and studies such as Law and Commerce must be "The Bottom". 
Egyptian media and social sectors classify students, colleges and science into The Top versus The Bottom. This is a dangerous discrimination as it frustrates all students joining faculties other than Medicine, Engineering and Pharmacy. These three faculties are the privileged, the reputed and the respected. This is an implication that students who study Economics, Languages and Arts are as unworthy as all other students except for those who are lucky enough to enter one of the three summit faculties. As a matter of fact, no civilisation or advancement can depend solely on three branches of human knowledge. Racism in education and knowledge makes most students adopt wrong beliefs about superior studies versus inferior studies, which will have devastating effects on social progress and satisfaction.

\section{Conclusion}

Racial discrimination, genetically-based polarization, nationality-based segregation, religion-based racism, genetic racism, skin-colour racism, scientific racism, anti- immigrants' racism, history-based polarisation and knowledge/educational racism stem from distorted ideologies that are deeply rooted in people's minds. Racist/polarised ideologies are proven to be spread in almost all life domains and amongst almost all social sections. These ideologies are detected and unveiled through critical analysis of discourse in an attempt to find a way out of racially-torn societies.

It is said that any study should participate in solving a current problem as this is to be a major concern of researches and researchers. This study reveals racism through discourse analysis as a primary step to suggest a solution that may mitigate racial practices. It seems that changing polarised/racist ideologies is a must because these ideologies give rise to negative behaviours. The first step to ideological change is the establishment of genetic, national, religious, scientific and educational equivalence. This can be fulfilled through teaching this principle of equivalence at schools from early childhood. Media should take care of their words and select them carefully so as not to use any racist references. All public figures and politicians should be blamed and criticised when uttering any racist comment.

It is not easy to change an ideology. But it is devastating to leave ideologies which tear societies apart. According to educational racism, this study, being discourse-focused, belongs to The Bottom. It is hoped that this paper may take part in issuing a change so that it may be considered of equal importance to medical papers in Egypt. 


\section{References}

Amer, M. 2017. Critical discourse analysis of war reporting in the international press: the case of the Gaza war of 2008-2009, Available at https:/www.nature.com/articles/s41599-017-0015-2.

Bhatia, A. \&Jenks, C.J. 2018. Fabricating the American dream in USmedia portrayals of Syrian refugees: A discourse analytical study, SAGE Publications.

Bonilla-Silva, E. 2009. Racism without racists: Color-blind racism and the persistence of racial inequality in the United States, (3rd ed.), Lanham, MD, Rowman and Littlefield.

Chilton, P. 2004. Analyzing political discourse: theory and practice, London and New York, Routledge.

Eissa, M. 2004. "Polarised discourse in the news", Social and Behavioral Sciences, 143, 70-90, DOI: 10.1016/j.sbspro.2014.04.225.

Fairclough, N. 1989. Language and power, London, Longman.

Fairclough, N. 1992. Discourse and social change, Cambridge, Polity Press.

Fairclough, N. 1995. Critical discourse analysis: The critical study of language, New York, Longman.

Fairclough, N. 2003. Discourse analysis. Textual analysis for social research, London \& New York, Routledge, Taylor \& Francis Group.

Fowler, R. 1991. "Critical linguistics", in K. Halmkjaer, (Ed.), The linguistic encyclopedia, London/New York, Routledge.

Fowler, R., Hodge, B., Kress, G., \& Trew, T. 1979. Language \& control, London, Routledge \& Kegan Paul. Gee, J. P. 1990. Social linguistics and literacies: ideology in discourses, London, Falmer Press.

Gee, J. P. 1996. Social linguistics and literacies: Ideology in discourses (2nd ed.), London:Taylor \& Francis

Hamilton, M.B. 1987. "The Elements of the concept of ideology", Political studies, Vol 35, Issue 1. SAGE Journals.

Herman, V. 1995. Dramatic discourse: dialogue as interaction in plays, London and New York, Routledge.

Hodge, B. 2012. Ideology, identity, interaction: Contradictions and challenges for critical discourse analysis, Available at https://www.lancaster.ac.uk/fass/journals/cadaad/wp-content/ uploads/2015/01/Volume-5_Hodge.pdf.

Jorgensen, M. \&Phillips, L.J. 2002. Discourse analysis as theory and method, SAGE Publications.

Jost, J. T. 2007. “Ideology”, In R F. Baumeister \& K D. Vohs (ed.) Encyclopedia of social psychology, SAGE Publications.

Levinson, S. 1983. Pragmatics, Cambridge, Cambridge University Press.

McCarthy, M. 1991. Discourse analysis for language teachers, Cambridge, Cambridge University Press.

Nemeth, D. 2006. "Ideology”, in B. Warf(ed.), Encyclopedia of Human Geography, SAGE Publications.

O'Halloran, K.A. 2005. "Mystification and social agent absences: A critical discourse analysis using evolutionary psychology”, Journal of Pragmatics,vol.37, no.12,pp.1945-1964.

Persson, E. \&Neto, L.M. 2018. "Ideology and discourse in the public sphere: A critical discourse analysis of public debates at a Brazilian public university", Discourse \& Communication, vol. 12, Issue, 3, SAGE Journals, DOI: 10.1177/1750481318757765.

Schiffrin, D., Tennen, D., \& Hamilton, D. 2001. "Introduction”, in D Schiffrin, D Tennen, \& D Hamilton (ed.), The handbook of discourse analysis, USA \&UK, Blackwell Publishers.

Szalay, L. b. Kelly, R.M. \& Moon, W.T. 1972. Ideology. Its meaning and measurement, SAGE Publications.

Van Dijk, T.A. 1993. "Principles of critical discourse analysis", Discourse \& Communication, SAGE Journals, Vol. 4, issue 2, pp. 249-283.

Van Dijk, T.A. 1998. Ideology. A Multidisciplinary approach, SAGE Publications Ltd.

Van Dijk, T.A. 2001a. “Critical discourse analysis”, in D. Schiffrin, D. Tennen, \& D. Hamilton (ed.), The Handbook of Discourse Analysis, USA \&UK, Blackwell Publishers.

Van Dijk, T.A. 2001b. "Discourse and Ideology", in T.A. Van Dijk (ed.), Discourse studies: $A$ multidisciplinary introduction, SAGE Publications Ltd. 
Van Dijk, T.A. 2002. Political discourse and ideology, Available at http://www.discourses.org/OldArticles/ Political\%20Discourse\%20and\%20Ideology.pdf.

van Dijk, T.A. 2006 a. "Politics, ideology, and discourse",, in K Brown(ed.), The Encyclopedia of language and linguistics, Vol. 9 Oxford, New York, Pergamon Press, pp. 728-740.

Van .Dijk,T.A. 2006b. "Ideology and discourse analysis”, Journal of Political Ideologies, Routledge, vol.11, issue, 2, pp.115-140, https://doi.org/10.1080/13569310600687908

Van Dijk, T.A. 2007. Ideology and discourse, A Multidisciplinary introduction, Available at http://www. discourses.org/UnpublishedArticles/Ideology\%20and\%20discourse.pdf

Van Dijk, T.A. 2013. "Ideology and discourse", in M Freeden \&M. Stears (ed.), The Oxford Handbook of Political Ideologies, Oxford, Oxford University Press.

Wodak, R. 2001. "What CDA is about-a summary of its history, important concepts and its developments", in R. Wodak \& M. Meyer (ed.), Methods of Critical Discourse Analysis, London, SAGE Publications.

Wodak, R., \& Reisigel, M. 2001. "Discourse and racism”, in D Schiffrin, D Tennen, \& D Hamilton (ed.), The Handbook of Discourse Analysis, USA \&UK, Blackwell Publishers. 